\title{
Month of Birth and Gifted Student Identification
}

Lee, SoonJoo*

Kim, KyoungDae**

\section{논문 요약}

This study has investigated whether school entrance monthly age works as an important factor in the identification of gifted students. The results of the analysis are as follows. First, the monthly age of entrance among students of the same grade is positively correlated with elementary, middle and high school gifted-student identification. Second, in this study we compared the ratio of successful candidates who were born in Mar-Ap.. and in Jan-Feb, to grasp more clearly the effect of entrance monthly age on gifted-student identification. We found that the number of students born in Mar-Apr among the successful candidates is much higher than the number of students born in Jan-Feb From these results, it is suggested that spring-born students who have entered school at an older age have higher academic achievement than their classmates and possibly an advantageous position in the gifted identification process.

Key words: school entrance monthly age, gifted identification, gifted students, duration gap, candidates, month of birth

\section{Introduction}

Why were 14 of 75 the richest men in world history born at the same time in the same country? ......

* Corresponding author, Prof. Hanbat National University

** Teacher, Korea Science Academy of KAIST 
The situation may come where students born in certain time enjoy good benefits, if select, classify and treat differently them based on the age. ... ... Most of parents would think whatever disadvantage their students experienced in kindergarten because of age delay will be disappeared in a moment. But the reality is not. A small profit which students born at the beginning of the year enjoy, like disadvantage students born at the end of the year experience, consistently last....... Economist Kelly Bedard and Elizabeth Dhuey recently compared grade in TIMSS (quadrennial mathematics and science tests for students around the world) and birth months of exam takers. ... ...

If classified 4th grade with intellectual equal on both sides of the basic date for school year, students born in the early belongs to top $18 \%$ : students born in the late period, on the other hand, stay in the top $68 \%$.

In this situation when you divide a group of gifted, obvious variation is bound to occur.-omitted- If select smart students as the top reading class and honors math class, the students born a few months soon enter the upper course and learn something better. In the following year they form upper group and in fact, do good job. And same goes for next year. -omitted- In four-year universities, the highest educational institutions, proficiency difference in the first step does not disappear. This effect lasts for a long time, because disadvantage in the beginning step works as an important factor in determining whether thousands of students enter the university or not, enter the middle class or not. ... ...

- From Malcom Gladwell's latest book, Outliers -

The above article is part of the contents of "Outliers", the New York Times No. 1 best-seller and Amazon, No. 1 non-fiction best-seller. This book created a huge sensation around the world. Malcolm Gladwell, the book's author, who is one of the top 10 most influential business thinkers, made the success rules of Outliers through original case analysis. What message are these rules conveying to society in the $21^{\text {st }}$ century?

The concept of Outliers presented in Gladwell's book can be defined as people who succeed beyond the norm or discover chances of success and exploit them. Gladwell points out the intellectually gifted as one outlier class who come to be part of the elite regardless of their origins. Of course, the variables that affect growth and development of gifted children can be very diverse. It is known that many different variables affect development of giftedness, including not only genetic factors which have been found to determine $70 \%$ of intelligence (Storfer, 1990), but also individual potential, measured by factors including motivation, interest, concentration, self confidence, self-esteem, and environmental factors divided into people, physical environment, education, events, and opportunities. However 
genetic factors remain the most important (Plomin, 1994) and many studies have presented evidence to show that giftedness in many areas is determined genetically (Gardner, 1983; Plomin, 1989). Individual also must be supported with environmental factors for the development of giftedness (Gagne, 1985; Piirto, 2000; Ziegler \& Heller, 2000). Winner (1997) concluded that individuality is more important than intelligence to the professional success of an individual. On the other hand, the systematic and intensive training that environments like home and school provide must be supported in order for inborn giftedness to grow and develop (Крутецкий , 1964; Лей тес, 1996; Хеллер, 1997).

Based on the following grounds, the position has become persuasive that among different variables affecting growth and development of gifted children, difference in cognitive development according to month of birth can serve as an important variable. First, the problem of the child's maturity must be considered (Elkind, 1987; Kinard \& Reinherz, 1986; Shepharp \& Smith, 1986; Uphoff, 1990). If a child is younger than other children in the same grade, this increases the probability that the child will experience more stress and failure in school because of the difference in cognitive maturity (Sharp, Hutchison \& Whetton, 1994). Second, there is a problem of age-appropriate curriculum. It is mainly composed of formal, logical, and abstract learning activities rather than play learning activities. Therefore it may not be suitable for young children (Sharp \& Whetton, 1994). Third, there is also a problem of teachers' preconceptions about children who are young for their year. Many teachers have low expectations for relatively young children and maintain the preconception that they have short attention spans and low interpersonal skills (Bell \& Daniels, 1990). These grounds grant persuasive power to the position that the age difference between children in the same grade plays an important role in determining their academic ability, especially the development of giftedness (Lee \& Park, 2008). Studies in Korea have shown that school entrance monthly age serve as a major factor in determining a child's academic abilities. Many education officials pay attention to the idea that monthly age difference between children of the same grade plays an important role in the development of academically poor students and the growth and development of gifted children. For example, Kim (2011) explored the effect of elementary school age, which is deternied by birth date and school entrance law, on college admission. The results of this study proved that older students at elementary school entry were likely to have better outcomes during college applications. Hong et al. (2010) published the following finding on South Korean students the "monthly 
age effect" on students academic achievement, or the relationship between student' birth months and academic achievement, lasted through until high school. Meanwhile, unlike these studies, which were targeted at average and worse-than-average students, in studies aimed at elementary and secondary gifted students (Lee \& Park, 2008), it was found that school entrance monthly age worked as an important factor in the development of gifted students.

These results support Gladwell's argument. He pinpointed that birth month serves as an advantage to those students born early, and a disadvantage to students born late; and that these factors can continue to have an effect on students' lives. In other words, students born earlier but at the same grade level as students born later can gain a better foothold for a successful life. However, among previous studies analyzing the effects of school entrance monthly age in South Korea, Kim (2011) studied the general student population and Hong et al. (2010) studied, worse-than-average, average, and excellent students, not gifted students. This study, in contrast, takes Gladwell's gifted outliers as its starting point. Lee \& Park (2008), for its part, was limited to elementary and middle school gifted students and based on data collected over two years, and as a result faces the following limitations. The effects of school entrance monthly age on identification of gifted students could not be analyzed more broadly by age and school levels, covering elementary, middle and high schools. Thus, it has been pointed out the relationship between the two variables of giftedness and academic success needs to be proved more extensively and comprehensively through follow-up study. Therefore, the present study expands the participants to gifted high school students and is based on minutely analyzed data collected for many year on the effects of elementary school entrance monthly age on gifted-student identification. Thus, we could investigate how the effect of school entrance monthly age changes according to grade level.

The results of this study will be the main issue in helping to raise interest in the school entrance system, and will be considered an important source material when education policymakers make decisions on school entrance rules. Based on these results, education professionals should be questioning whether there is a policy to reduce a child's potential ability in the present educational systems, and to seek for the education policy to minimize these possibilities.

The research problems of this study are as follows. 
1. Which aspects will be assumed in the school entrance monthly age of the elementary range of gifted examination candidates?

2. Which aspects will be assumed in the school entrance monthly age of the middle range of gifted examination candidates?

3. Which aspects will be assumed in the school entrance monthly age of the higher range of gifted examination candidates?

4. Which aspects will be assumed regarding the number of students born in Jan·Feb and born in Mar·Apr from among the gifted examination candidates?

\section{Preceding Studies}

\section{The school entrance monthly age and academic ability}

Research to illuminate the relationships between the duration gap which exists between the children in the same grade and the academic research has been conducted for relatively a long time. However, despite these circumstances, clear evidence on this issue has still not been reached, and the results from researches of this subject are also showing a slightly different aspect. The results of previous research uncovering the relationships between children's school entrance monthly age and their academic ability are divided into the following two groups:

First, the research results denied any relations between the child's school entrance monthly age and their academic ability. Mayer and Knutson's study conducted in 1999 presented analysis results stating that younger children seemed to achieve better academic results than older children. In the study of Bibby et al. (1996), looking at learning ability tests (IQ tests, math ability tests, social skills tests), found that younger children's learning ability was not lower than that of children in the same grade who had earlier birthdays, and Wilson (2000) found that children born in the summer, with a very young age, compared to children born in autumn, had the same learning ability and cognitive ability as children born in the summer; both of these groups had higher than average marks.

The second group of research results shows a relationship between a child's school entrance monthly age and their academic ability. These studies conclude that younger 
children seem to have a relatively low academic ability. Certain research on the education system of the United Kingdom is a typical example. In the UK, the new school year begins on September 1. These researches say that children born in autumn (in the UK, children born from September to December are the oldest a at a particular grade level) are more academically successful than children born in the spring (from January to April). Sutton (1967), and Russell and Startup (1986) uncovered lower academic abilities in children born in the summer (the youngest children). In addition, Gilles (1993), and Jinks (1964) showed that children born in the summer are relatively more likely to be in recruiting class or special classes, and Wallingford and Prout (2000) showed that children born in the summer are much more prevalent in the group needing supplemental learning and depending on supplemental educational assessment $(\mathrm{SEN})$ results.

Mortimore et al. (1988), concentrating on more than 2,000 elementary school students in London, found that the reading ability of summer born children, who are the youngest at each grade level, declined more than that of children born in the fall. This decline shows a similar pattern to their mathematical ability. Sharp, Hutchison and Whetton (1994) found that children born in the summer seem to have remarkably lower scores than older children in English, mathematics and science in KSI' SATS. These results show that school entrance monthly age works as an important factor to determine a child's academic ability.

In addition, Foxman, Ruddock and McCallum (1990) showed that the math ability of middle school children born in the fall is approximately $15 \%$ higher than that of children born in the summer. Therefore, they formed the conclusion that school entrance monthly age goes on to affects students into middle school. This phenomenon has been revealed through several recent studies showing that school entrance monthly age has an effect on the UK national curriculum and GCSE results (Dorset Education Authority, 1991; Giles, 1993; Hedger, 1992). According to Sharp (1995), children born in the summer showed 2 - 3\% lower grades compared to children born in autumn. Also, the percentage of students accepted into university that were born in the summer was lower than that of other children. Croll and Moses (1985) said that the underachievers in Reading Comprehension consisted of $67 \%$ children born in summer, $28 \%$ spring and $6 \%$ autumn. From this series of studies Carroll (1992) came to the conclusion that children who are the youngest at each grade level represent the "underachiever" group.

Orme (1962) pointed out that these unequal educational conditions, which are determined 
by birth month, cause a loss of opportunity to develop academic ability in the children born in summer. Based on this, Fogelman and Gorbach (1978) suggested that children born in the summer should be required to be admitted late to kindergarten or school for one or two semesters. Davis and Trimble (1978), Cosden, Zommer, and Tuss (1993), and Crosser (1986) advised parents with children born in the summer to let their children go to kindergarten for an extra year. Actually, children who enter school one year later show much better adaptation to school life and academic work than do children who entered school one year earlier, and the children who are the youngest at each grade level are not ready to start school life and it does not fit their developmental stage to provide them with a normal school curriculum. Hence, these environments often act as a cause of the failure and stress.

In South Korea the issue of the relationship between school entrance monthly age and academic ability has begun to be explored in recent years, and studies found a strong correlation between the two variables mentioned. Kim (2011), targeted at all students can be mentioned. Kim compared college admittance rates between students born in Jan or Feb and those born in other months. Relatively older students were likely to have better educational outcomes during the first college entrance.

Hong et al. (2010) found a "monthly age effect" on student academic achievement on the basis of PISA 2006 and TIMSS 2007 data. An academic achievement gap by birth month appeared in groups with lower than average and higher than average academic ability. In a study on South Korea's gifted students (Lee \& Park, 2008), it was also shown that students who entered school in full age much more often were accepted into the education center for gifted students than were students of a younger age.

So the following implications can be found. Difference in cognitive development by age serves as an important variables in the formation of academic ability. However, as mentioned earlier, this study was faced with the following limitations. Data was collected for only two years, and the object of study was limited to elementary and middle schools. As a result, the need for follow up study has been pointed out. In the current study, based on data collected for an extended period of time, we analyzed aspects of gifted student identification, for elementary, middle and high school students by school entrance monthly age. 


\section{The growth and development of gifted children}

There is little disagreement on one point: that both traits inherited from parents and environment where an individual grows up can affect growth and development of giftedness. In other words, giftedness is developed to a higher level, when we use train and practice everyday knowledge and ability in the fields where giftedness appears. For example, these abilities will develop, only while doing physical training, working on problem solving exercises at school (e.g., word puzzle solving or creativity exercises), volunteering, etc. In addition, individual traits should work for the growth and development of gifted children. Gagne (1985) included in this category self-efficacy, self-esteem, self-learning attitude, high motivation (interest, concentration), etc., and Ziegler and Heller (2000) included need to overcome failure, high achievement motivation, combating stress, knowing a learning strategy and using it, self-efficacy, self-regulation, etc. in the category of individuality. Piirto (2000) pointed out that creative people of world class have the following personal characteristics in common: imagination, insight, openness, sensitivity, patience, flexibility, adventurousness, self-efficacy, patience for ambiguity, and will power. After analysis of several studies on the development of giftedness, Winner (1997) put forward the following formula regarding personal characteristics as key elements for success: individuals will be able to reach up to outstanding accomplishments as exercises and, training, enlarge their experience and they use learning strategies to overcome difficult problems and failure, controlling their own selves autonomously and self-directedly on the basis of self-confidence and self-efficacy. The motivation presented in Renzulli's definition has also been raised as an important characteristic affecting the development of giftedness. In other words, when motivation is strong, people determine the best course of action, initiate action, and maintain a continuous action, until their own desires are satisfied (Jo \& Lee, 2001).

Giftedness is certainly genetic, but cognitive development, as well as environmental factors and personal characteristics, plays a role in the development of giftedness. Children's development and growth serve as major factors in adjustment to school life, so the child's level of maturity can serve as an important variables in the development of giftedness (Sharp, Hutchison \& Whetton, 1994; Lee \& Park, 2008). Moreover, in the cases of kindergarten and early elementary school children, the school curriculum consisted of formal, logical, and abstract learning activities that could be less suitable for younger 
children than for other children in the same grade (Sharp et al.. 1994). Therefore, these children have lower academic ability, are more likely to be low achievers, and show worse results in the gifted identification stage as well (Kim, 2011; Hong et al., 2010; Lee \& Park, 2008). Therefore, the child's natural maturity acts as an important factor influencing academic ability and development of giftedness.

\section{Research methods}

\section{The subject of study}

To analyze if the age gap that exists between students in the same grade has an effect on academic achievement, we made gifted students from elementary to high schools the subject of study. All of them began elementary school on March 2 by the school entrance system of South Korea, where the school year begins in March Some subjects were participants for the entrance examination of the " $\mathrm{K}$ " center for gifted students; others were, students of South Korea's top ranking gifted high school. The high school gifted group consists of successful candidates for gifted - high school entrance examinations conducted from 2003 to 2007. The elementary and middle school gifted groups consist of both participants and successful candidates for entrance examinations conducted from 2005 to 2008. The elementary school candidates in the middle school entrance examinations conducted in 2006 took only the second and third exams, without the first, since in 2007 and 2008, immunity for the first exam was granted to elementary school students of gifted education institutes run by the universities and provincial and metropolitan offices of education. In this study, the students entered school up to one year apart, and were excluded from the exam to uncover the effects of monthly age gap among students in the same grade on academic achievement.

This study also compared success ratio by birth season of each group, including regular students, that is, students born at the same time as the gifted students and compared with the gifted groups (Annual Report of Vital Statistics for Population Movement, 1995 - 1996). These subjects were classified into spring-, summer-, and winter-born groups. Students born from Mar to Jun, who are the oldest at each grade level, are classified in the spring-born 
group, students born from Jul to Oct into the summer group, and students born from Nov to Feb into the winter group. We analyzed the relations between school entrance monthly age and gifted identification. Actually students born in spring were admitted the school from six years nine months to seven years old, students in summer from six years five months to six years eight months, and students in winter from six years one month to six years four months, so there is a 12-month age gap between students born in Mar and students born in Feb We compared the ratio of application to success in the gifted identification exam for two groups - students born in Jan and Feb and students born in Mar and Apr - to illuminate relations between age gap and gifted identification. The information discussed above is shown in $<$ Table $1>$.

$<$ Table 1> Subject of study

\begin{tabular}{|c|c|c|c|c|}
\hline Year & Step & Year and Month of Birth & Number & Total \\
\hline \multirow{4}{*}{$\begin{array}{c}\text { Elementary } \\
\text { School }\end{array}$} & 2005 School Year & Mar 1994-Feb 1995 & 150 & \multirow{4}{*}{1,056} \\
\hline & 2006 School Year & Mar 1995-Feb 1996 & 251 & \\
\hline & 2007 School Year & Mar 1996-Feb 1997 & 361 & \\
\hline & 2008 School Year & Mar 1997-Feb 1998 & 294 & \\
\hline \multirow{4}{*}{$\begin{array}{l}\text { Middle } \\
\text { School }\end{array}$} & 2005 School Year & Mar 1992-Feb 1993 & 141 & \multirow{4}{*}{1,167} \\
\hline & 2006 School Year & Mar 1993-Feb 1994 & 333 & \\
\hline & 2007 School Year & Mar 1994-Feb 1995 & 435 & \\
\hline & 2008 School Year & Mar 1995-Feb 1996 & 258 & \\
\hline \multirow{5}{*}{$\begin{array}{l}\text { High } \\
\text { School }\end{array}$} & 2003 School Year & Mar 1987-Feb 1988 & 144 & \multirow{5}{*}{721} \\
\hline & 2004 School Year & Mar 1988-Feb 1989 & 144 & \\
\hline & 2005 School Year & Mar 1989-Feb 1990 & 145 & \\
\hline & 2006 School Year & Mar 1990-Feb 1991 & 144 & \\
\hline & 2007 School Year & Mar 1991-Feb 1992 & 144 & \\
\hline
\end{tabular}

\section{Gifted Identification Phase}

The identification of gifted students for elementary and middle schools was carried over to stages 3 or 4 . These identification stages were different each year, depending on the circumstances of the year. In the first stage, candidates were picked out by principal recommendations based on their school records. In the second stage, a basic math and science - achievement exam was conducted, and in the third stage, students sat a creative - 
problem solving exam. In this step, students were given subjective questions in an open style (both questions in scaffolding style and questions in PBL style) and were required to present their idea as a problem-solving process, that is, demonstration of logical thinking skills was considered a greater asset than merely giving the correct answer. In the final identification stage, performance assessments were carried out. Here, lectures on theory were conducted for candidates, on which the experimental evaluation was afterward based.

The following are the phases of the gifted identification for high school students.

In the first stage, identification was conducted by examining the candidates' academic histories. In the second stage, a paper based creative-problem solving exam was administered. In the third stage, identification was based on performance assessments investigating scientific - problem solving ability, high-order thinking ability, creativity, and personality.

\section{Data Processing Method}

After the identification process, data was collected on a computational processing program (SPSSPC+). The study analyzes the significance of differences among groups with a chi-square test, which proves the effects of school entrance monthly age on the gifted identification process.

\section{Results of study}

\section{Seasonal distribution of birth of Korean Children}

Before any analysis of the main research questions, the number of births by season in South Korea was compared with the distribution among students who applied for the elementary, middle and high school gifted exams.

According to $<$ Table $2>$, the birth rate in winter is the highest among the seasons for years from Mar 1987 to Feb 1995. This difference is statistically significant $(\mathrm{p}<.001)$. In contrast, from Mar 1995 to Feb 1996 the rate of summer births was highest, then winter, then spring. The following results were obtained. 
$<$ Table 2> Seasonal distribution of birth of Korean children

\begin{tabular}{|c|c|c|c|c|c|}
\hline \multirow{2}{*}{ Year and Month of Birth } & \multicolumn{3}{|c|}{ Season of birth } & \multirow{2}{*}{ expected } & \multirow{2}{*}{$\chi^{2}$} \\
\hline & Spr. & Sum. & Win. & & \\
\hline Mar 1987 Feb 1988 & $\begin{array}{c}187,663 \\
(90)\end{array}$ & $\begin{array}{c}200,292 \\
(96)\end{array}$ & $\begin{array}{c}240,071 \\
(115)\end{array}$ & $\begin{array}{c}209,342 \\
(100)\end{array}$ & $7146.93 * * *$ \\
\hline Mar 1988 Feb 1989 & $\begin{array}{c}179,657 \\
(85)\end{array}$ & $\begin{array}{c}205,590 \\
(97)\end{array}$ & $\begin{array}{c}249,598 \\
(118)\end{array}$ & $\begin{array}{c}211,615 \\
(100)\end{array}$ & $11815.43 * * *$ \\
\hline Mar 1989 Feb 1990 & $\begin{array}{c}185,016 \\
(86)\end{array}$ & $\begin{array}{c}205,979 \\
(96)\end{array}$ & $\begin{array}{c}254,258 \\
(118)\end{array}$ & $\begin{array}{c}215,084 \\
(100)\end{array}$ & $11723.71 * * *$ \\
\hline Mar 1992 Feb 1993 & $\begin{array}{c}226,509 \\
(94)\end{array}$ & $\begin{array}{c}237,600 \\
(98)\end{array}$ & $\begin{array}{c}261,424 \\
(108)\end{array}$ & $\begin{array}{c}241,844 \\
(100)\end{array}$ & $2632.06 * * *$ \\
\hline Mar 1993 Feb 1994 & $\begin{array}{c}231,638 \\
(97)\end{array}$ & $\begin{array}{c}228,885 \\
(96)\end{array}$ & $\begin{array}{c}252,755 \\
(106)\end{array}$ & $\begin{array}{c}237,759 \\
(100)\end{array}$ & $1434.62 * * *$ \\
\hline Mar 1994 Feb 1995 & $\begin{array}{c}236,628 \\
(99)\end{array}$ & $\begin{array}{c}230,894 \\
(97)\end{array}$ & $\begin{array}{c}247,885 \\
(104)\end{array}$ & $\begin{array}{c}238,469 \\
(100)\end{array}$ & $626.62 * * *$ \\
\hline Mar 1995 Feb 1996 & $\begin{array}{c}228,328 \\
(93)\end{array}$ & $\begin{array}{c}262,926 \\
(107)\end{array}$ & $\begin{array}{c}248,856 \\
(101)\end{array}$ & $\begin{array}{c}246,703 \\
(100)\end{array}$ & $2454.20 * * *$ \\
\hline
\end{tabular}

\section{Analyses of the school entrance monthly age of elementary-school gifted-examination candidates}

According to the analysis of the school entrance monthly age of candidates for the elementary school gifted examination, from 2005 to 2008, the percentage of these students born in the spring was significantly higher than in the other groups, unlike children generally. Except for the final successful group in 2008, the number of students born in the spring was the highest every year.

When the difference in the number of students born in spring and winter is looked at, we can see that there are 3.09 times more students born in spring than students in winter in, for instance, 2006. further, when the number of candidates is compared to expectations, the number of students born in spring ranged from equal to expectations to $70 \%$ above expectations. In contrast, the number of students born in summer $(-26 \% \sim+4 \%)$ and winter $(-45 \% \sim+6 \%)$ is below expectations overall from 2005 to 2008. From these results, we can see that school entrance monthly age serves as a very important factor in elementary school gifted identification. In other words, we can understand that students born in spring who are older at each grade than any other group have very high potential to be selected 
as gifted, while students born in winter who are the youngest have very low potential for identification. When we look at the data from [Picture 1]-[Picture 4], the relationship between school entrance monthly age and gifted identification can be easily understood.

<Table 3> Candidates for elementary school gifted student identification, according to school entrance monthly age

\begin{tabular}{|c|c|c|c|c|c|c|}
\hline \multirow{2}{*}{ Year } & \multirow{2}{*}{$\begin{array}{c}\text { Identification } \\
\text { Step }\end{array}$} & \multicolumn{3}{|c|}{ Season of Birth } & \multirow{2}{*}{ expected } & \multirow{2}{*}{$\chi^{2}$} \\
\hline & & Spr. & Sum. & Win. & & \\
\hline \multirow{3}{*}{2005} & $1^{\text {st }}$ & $102(131)$ & 76(98) & $55(71)$ & $77.66(100)$ & $14.27 * * *$ \\
\hline & $2^{\text {nd }}$ & $52(111)$ & 49(104) & $40(85)$ & 47(100) & 1.65 \\
\hline & Final & $34(115)$ & $31(104)$ & $24(81)$ & 29.67(100) & 1.77 \\
\hline \multirow{4}{*}{2006} & $1^{\text {st }}$ & $182(123)$ & $128(86)$ & 134(91) & $148(100)$ & $11.83 * *$ \\
\hline & $2^{\text {nd }}$ & $116(127)$ & $72(79)$ & $86(94)$ & $91.33(100)$ & $11.06 * *$ \\
\hline & $3^{\text {rd }}$ & $51(151)$ & $25(74)$ & $25(74)$ & $33.67(100)$ & $13.38 * *$ \\
\hline & Final & $34(170)$ & $15(75)$ & $11(55)$ & 20(100) & $15.1 * * *$ \\
\hline \multirow{4}{*}{2007} & $1^{\text {st }}$ & $302(129)$ & $196(84)$ & $206(88)$ & $234.67(100)$ & $29.19 * * *$ \\
\hline & $2^{\text {nd }}$ & 147(137) & $83(77)$ & 93(86) & $107.67(100)$ & $22.01 * * *$ \\
\hline & $3^{\text {rd }}$ & 43(134) & 25(78) & 28(88) & $32(100)$ & 5.81 \\
\hline & Final & $23(115)$ & $16(80)$ & $21(105)$ & $20(100)$ & 1.3 \\
\hline \multirow{3}{*}{2008} & $1^{\text {st }}$ & $232(124)$ & 187(100) & $142(76)$ & 187(100) & $21.65 * * *$ \\
\hline & $2^{\text {nd }}$ & 116(116) & 102(102) & 83(83) & $100.33(100)$ & 5.46 \\
\hline & Final & $18(100)$ & $17(94)$ & 19(106) & $18(100)$ & 0.111 \\
\hline
\end{tabular}

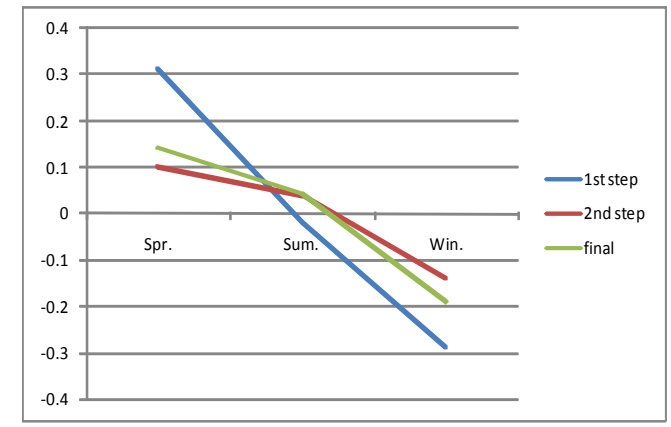

[Picture 1] Elementary Gifted Identification in 2005')

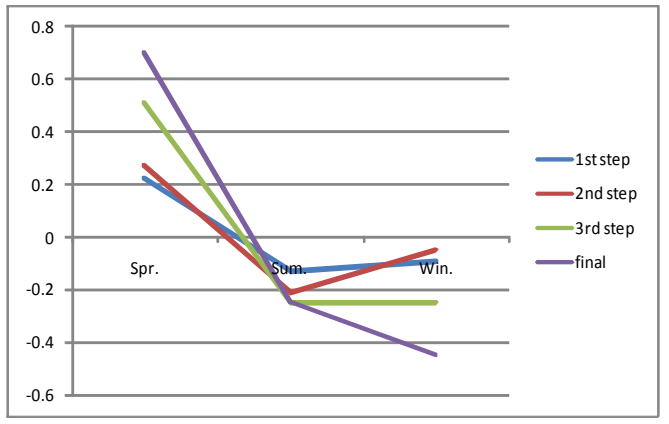

[Picture 2] Elementary Gifted Identification in 2006

1) " $n$ " (seasonal birth value presented in the graph) was calculated by the following ways: $\mathrm{n}=$ (the number of births- the average number of births) / the average number of births This calculated ways was used to compare the difference between the birth rates more clearly. 


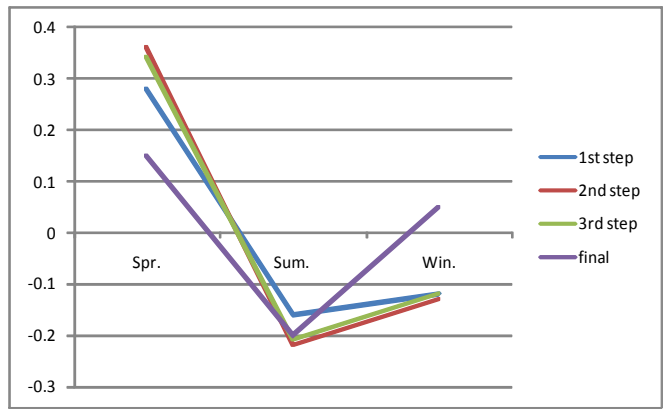

[Picture 3] Elementary Gifted Identification in 2007

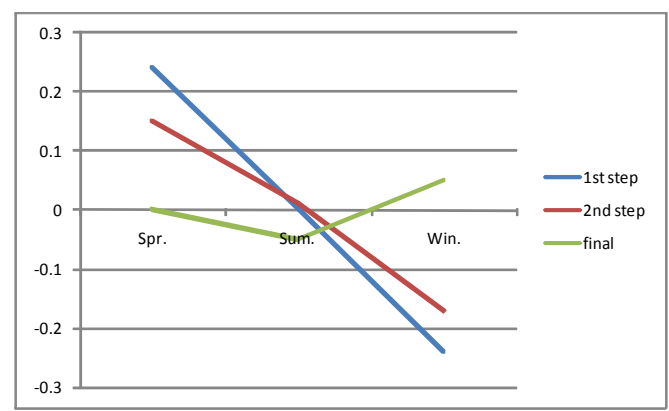

[Picture 4] Elementary Gifted Identification in 2008

As shown in $\langle$ Table $4>$, the highest number of middle school gifted candidates were born in spring, and for children in general, in winter. This difference was of statistical significance.

Through these results, we concluded that the possibility to be selected as gifted increases with increased age relative to one's cohort. When the number of births by season is analyzed, based on expectations, this phenomenon appears more clearly. The data on middle school gifted identification from 2005 to 2008 show that the number of students born in spring is $+11 \% \sim+37 \%$ above expectations. In contrast, the number of students born in winter is $-6 \% \sim-26 \%$ below expectations. This phenomenon can be identified through the data in [Picture 5] [Picture 8].

$<$ Table $4>$ Candidates for middle school gifted identification, by school entrance monthly age

\begin{tabular}{|c|c|c|c|c|c|c|}
\hline \multirow{2}{*}{ Year } & \multirow{2}{*}{ Identification Step - } & \multicolumn{3}{|c|}{ Season of Birth } & \multirow{2}{*}{ expected } & \multirow{2}{*}{$\chi^{2}$} \\
\hline & & Spr. & Sum. & Win. & & \\
\hline \multirow{3}{*}{2005} & $1^{\text {st }}$ & $52(111)$ & 49(104) & $40(85)$ & $47(100)$ & 1.65 \\
\hline & $2^{\text {nd }}$ & 42(116) & $33(91)$ & $34(94)$ & $36.33(100)$ & 1.33 \\
\hline & Final & $34(115)$ & $31(104)$ & $24(81)$ & $29.67(100)$ & 1.77 \\
\hline \multirow{2}{*}{2006} & $2^{\text {nd }}$ & 145(126) & 103(89) & $98(85)$ & 115.33(100) & $11.55 * *$ \\
\hline & Final & $58(122)$ & $48(101)$ & $37(78)$ & 47.67(100) & 4.62 \\
\hline \multirow{4}{*}{2007} & $1^{\text {st }}$ & 143(129) & $93(84)$ & $97(87)$ & $111(100)$ & $13.90 * * *$ \\
\hline & $2^{\text {nd }}$ & $210(137)$ & 136(89) & $115(75)$ & 153.67(100) & $32.41 * * *$ \\
\hline & $3^{\text {rd }}$ & $65(125)$ & $48(92)$ & $43(83)$ & 52(100) & 5.11 \\
\hline & Final & 40(130) & $28(91)$ & $24(78)$ & $30.67(100)$ & 4.52 \\
\hline \multirow{3}{*}{2008} & $1^{\mathrm{st}}$ & $110(120)$ & $87(95)$ & $77(84)$ & 91.33(100) & $6.27 *$ \\
\hline & $2^{\text {nd }}$ & $212(120)$ & 166(94) & 153(86) & $177(100)$ & $10.85 * *$ \\
\hline & Final & $60(131)$ & $43(94)$ & $34(74)$ & $45.67(100)$ & $7.63 *$ \\
\hline
\end{tabular}




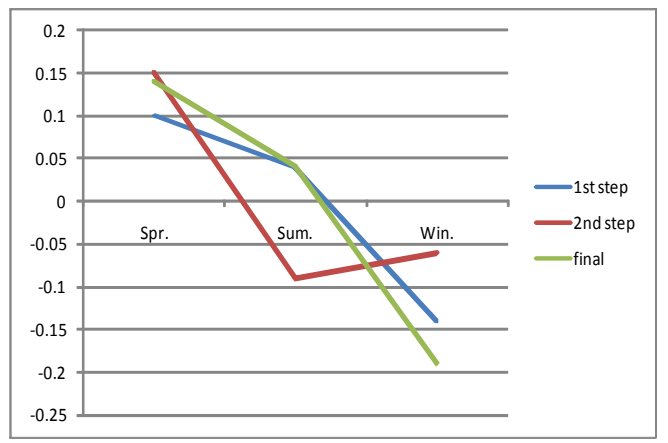

[Picture 5] Middle Gifted Identification

in 2005

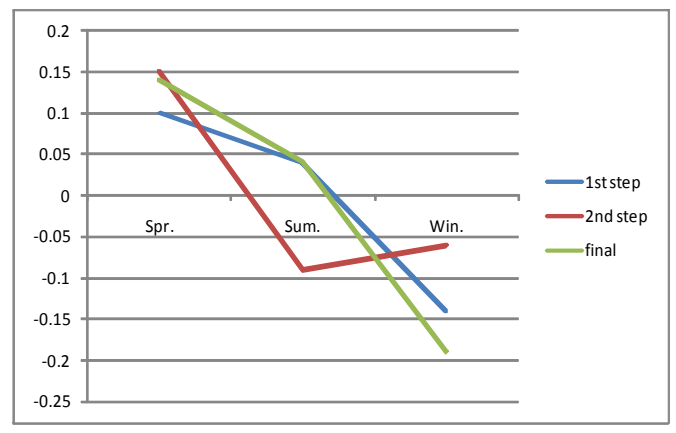

[Picture 7] Middle Gifted Identification

in 2007

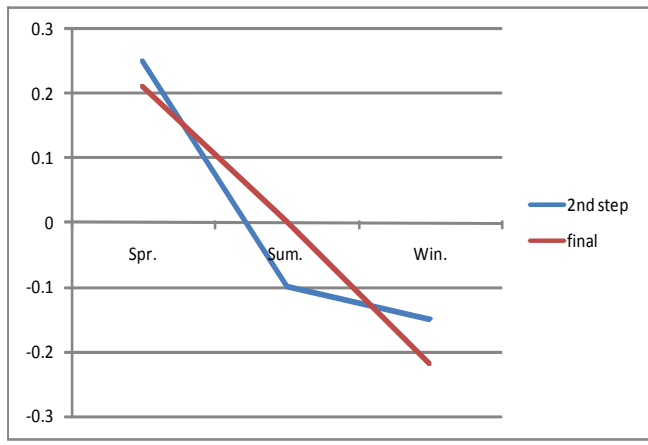

[Picture 6] Middle Gifted Identification

in 2006

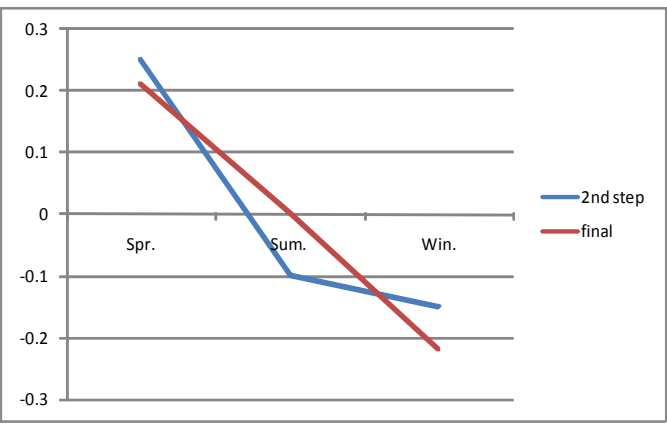

[Picture 8] Middle Gifted Identification

in 2008

\section{Analysis of school entrance monthly age of high school gifted students}

The analysis of school entrance monthly age of gifted high school students from 2003 to 2007 shows that school entrance monthly age continues to affect students up until high school gifted identification, that is, the number of students born in the spring is significantly higher than in the other seasons (see [Picture 9]). These differences were statistically significant in the case of 2007 and in total (2007, p<.01; total group, $\mathrm{p}<.001)$. Through these results, we can conclude that students who enter school at an older age are in a better position to be chosen in high school gifted student identification. Compared to expectations, this phenomenon is shown more definitely, that is, the number of spring births in all groups of high school gifted students from 2003 to 2007 is far above the expected value 
$(+9 \% \sim+37 \%)$. On the other hand, the birth rates in all other seasons are below the expected value $(-30 \% \sim+1 \%)$.

$<$ Table 5> School entrance monthly age of gifted high school students

\begin{tabular}{ccccccc}
\hline \multirow{2}{*}{ Year } & $\begin{array}{c}\text { Identification } \\
\text { Step }\end{array}$ & \multicolumn{3}{c}{ Season of Birth } & \multirow{2}{*}{ expected } & \multirow{2}{*}{$\chi^{2}$} \\
\cline { 3 - 5 } 2003 & Final & $58(121)$ & $49(102)$ & $37(77)$ & $48(100)$ & 4.62 \\
2004 & Final & $61(128)$ & $43(90)$ & $39(82)$ & $47.67(100)$ & 5.76 \\
2005 & Final & $57(119)$ & $45(94)$ & $42(88)$ & $48(100)$ & 2.62 \\
2006 & Final & $53(109)$ & $49(101)$ & $42(87)$ & $48(100)$ & 1.29 \\
2007 & Final & $66(137)$ & $34(70)$ & $45(93)$ & $48.33(100)$ & $10.93 * *$ \\
\hline Total & Final & $295(121)$ & $220(90)$ & $215(88)$ & $243.33(100)$ & $18.95 * * *$ \\
\hline
\end{tabular}

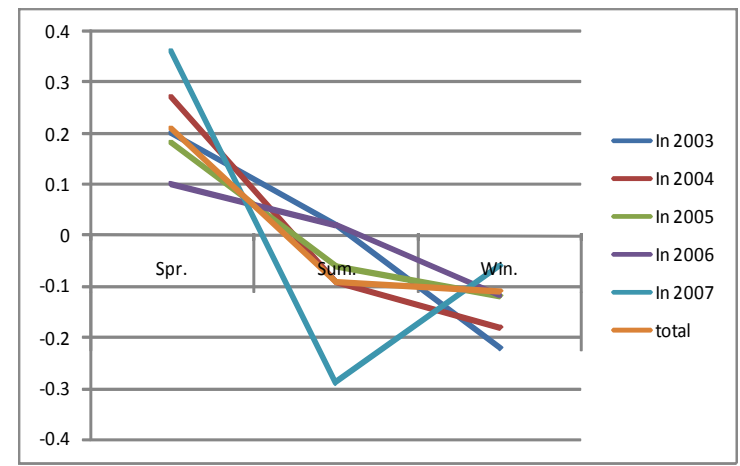

[Picture 9] High School Gifted Identification from 2003 to 2007

\section{Comparison between the ratio of the gifted students born in Jan or Feb and of those born in Mar-Apr}

The ratios of students born in Mar-Apr ("Mar-Apr"; the oldest group in every grade) and those born in Jan-Feb ("Jan-Feb"; the youngest group in every grade) were compared from among the successful candidates to grasp more clearly the effect of school entrance monthly age on gifted identification. As shown in [Picture 10], the number of students in Mar-Apr that were among the final selected gifted students is much higher than the number in Jan-Feb. In the case of elementary school students from 2005 to 2008, the number of successful candidates in Mar-Apr was from two times to 4.2 times higher than that of 
applicants in Jan-Feb The number of students in Mar-Apr is shown to be as much above the expected value as the number in Jan-Feb is below the expected value. In the case of middle school students, Mar-Apr is $64 \%$ above the expected value, making this the highest value for Mar-Apr. The higher values for Mar-Apr continue until high school. The difference is statistically significant in elementary and middle school in 2006, and 2007 and in high school in 2004.

$<$ Table 6> Comparison of Jan-Feb and Mar-Apr numbers across years and school stages

\begin{tabular}{|c|c|c|c|c|c|c|}
\hline \multirow{2}{*}{ Step } & \multirow{2}{*}{ Year } & \multicolumn{2}{|c|}{ Season of Birth } & \multirow{2}{*}{$\begin{array}{c}\text { Difference between } \\
\text { Jan-Feb and } \\
\text { Mar-Apr(times) }\end{array}$} & \multirow[b]{2}{*}{ expected } & \multirow{2}{*}{$\chi^{2}$} \\
\hline & & Jan.-Feb. & Mar.-Apr. & & & \\
\hline \multirow{4}{*}{$\begin{array}{c}\text { Elementary } \\
\text { School }\end{array}$} & 2005 & $10(67)$ & 20(133) & 2 & $15(100)$ & 3.33 \\
\hline & 2006 & $5(38)$ & $21(162)$ & 4.2 & $13(100)$ & $9.84 * *$ \\
\hline & 2007 & $8(43)$ & $29(157)$ & 3.6 & $18.5(100)$ & $11.91 * * *$ \\
\hline & 2008 & $6(60)$ & $14(140)$ & 2.3 & $10(100)$ & 3.2 \\
\hline \multirow{4}{*}{$\begin{array}{l}\text { Middle } \\
\text { School }\end{array}$} & 2005 & 23(94) & 26(106) & 1.1 & $24.5(100)$ & 0.18 \\
\hline & 2006 & $5(36)$ & 23(164) & 4.6 & $14(100)$ & $11.57 * * *$ \\
\hline & 2007 & $12(51)$ & 35(149) & 2.9 & $23.5(100)$ & $11.25 * * *$ \\
\hline & 2008 & 19(90) & 23(110) & 1.2 & $21(100)$ & 0.38 \\
\hline \multirow{5}{*}{$\begin{array}{l}\text { High } \\
\text { School }\end{array}$} & 2003 & $22(90)$ & 27(110) & 1.2 & $24.5(100)$ & 1.76 \\
\hline & 2004 & $19(67)$ & 38(133) & 2 & $28.5(100)$ & $6.33 *$ \\
\hline & 2005 & $27(89)$ & $34(111)$ & 1.3 & $30.5(100)$ & 0.8 \\
\hline & 2006 & $22(86)$ & 29(114) & 1.3 & $25.5(100)$ & 0.96 \\
\hline & 2007 & $16(86)$ & $21(114)$ & 1.3 & $18.5(100)$ & 0.6 \\
\hline
\end{tabular}

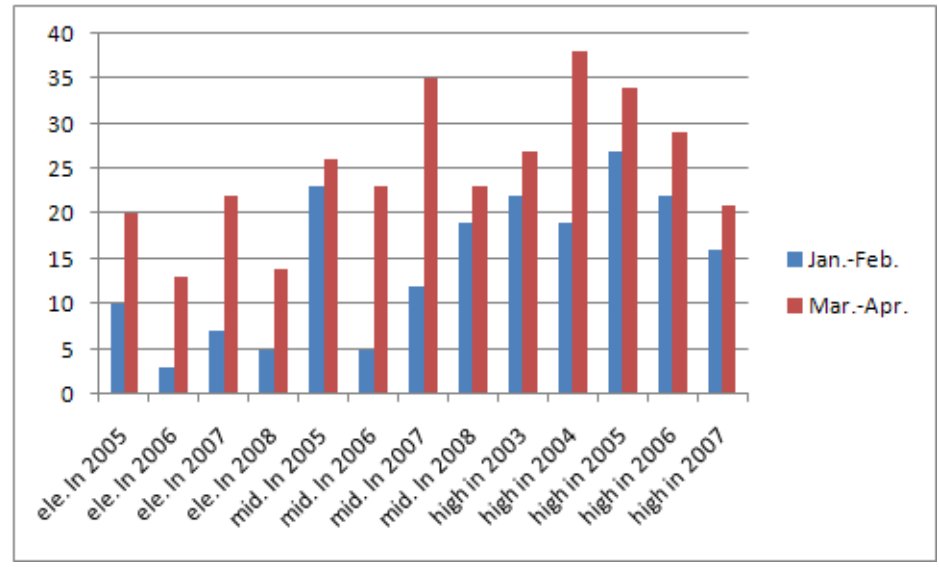

[Picture 10] Comparison of Jan-Feb and Mar-Apr numbers across years and school stages 


\section{Conclusion and Discussion}

A large number of preceding studies conducted to find factors affecting students' academic ability have reached the conclusion that differences in academic ability can be caused by school entrance monthly age. This study has investigated whether school entrance monthly age works as an important factor in the identification of gifted students (using South Korean gifted identification materials compiled from 2005 to 2008 in elementary and middle schools and from 2003 to 2007 in high schools).

The results of the analysis are as follows.

First, the monthly age gap stemming from school entrance time among same grade students is positively correlated with elementary and middle school gifted identification. In other words, according to the results of the analysis of the school entrance monthly age of candidates in the gifted identification process, the number of successful students born in the spring is extraordinarily larger than in other seasons. This phenomenon is opposite to the birth rate by season of the general student population born at the same time as the gifted sample. In the case of students in general born from Mar 1987 to Feb 1995, the birth rate of winter-born students is the highest each year. From this result, we can see that the oldest students in a cohort have much more of a chance of being selected as gifted, and that the monthly age gap within a cohort works as an important factor affecting not only academic ability in general, but also the identification of gifted students in particular. These results give support to the results of preceding studies (e.g., Foxman et al., 1990) suggesting that school entrance monthly age can be an important factor in determining academic ability, not only in elementary school, but also in middle school.

Second, in this study the birth season of gifted high school students is analyzed to reveal what effect school entrance monthly age has on academic ability and gifted identification. According to the analysis, the number of students born in spring is extraordinarily more than that of those born in other seasons. From this result we can conclude that school entrance monthly age also has an impact on high school gifted identification. For the entire group of gifted students selected from 2003 to 2007, the number born in the spring is far more than that born in other seasons,; these birth numbers attain statistical significance. When these numbers are analyzed by grade, every gifted cohort shows this elevation in the 
number of spring births. However, a statistically significant difference is shown only in the case of 2007 (and overall, as discussed above).

Thirdly, in this study we compared the ratio of successful gifted program candidates who were born in Mar or Apr to that of those born in Jan and Feb, to grasp more clearly the effect of school entrance monthly age on gifted identification. The number of successful candidates in Mar-Apr is much higher than that in Jan-Feb, and this difference is statistically significant.

From these results, it is suggested that spring-born students, who in South Korea have entered school at an older age, have higher academic achievement than their classmates and the possibility of an advantageous position in the gifted program identification process. This effect continues into high school. This is due to the difference in cognitive maturity at the time of admission to school. From these results, we can conclude that the rule of outliers' success mentioned at the beginning of this study also applies to the gifted identification processes.

Summing up, the results of previous studies and this study taken together will come lead to the following result conclusion. Many South Korean studies (Kim, 2011; Hong et al., 2010; Lee \& Park, 2008) analyzing the effect of school entrance monthly age on the academic ability pointed out that this effect of school entrance monthly age, which does not appear in other developed countries such as Finland (Hong et al., 2010), has been clearly shown in the poor low-achieving, average, and gifted student populations in South Korea. Through this series of studies we can see that there is some foundation for an increased focus on of issues that poor students can systematically encounter because of reckless early admission of young children and the lack of special guidance for these children action for that after school entry. If the monthly age at which a child enters school proves to be the chief factor not only in academic ability of low- and average-achieving students, but also in elementary, middle and high school gifted identification, then we need to develop a new school entrance system and teaching methods that are impartial to the monthly age of students and do not disadvantage students who enter school at a younger age and are therefore likely to have inferior academic abilities.

A prospective school entrance system with two or three intakes a year can be considered as one solution to the above mentioned problem. In fact, several countries are currently trying to operate a flexible school entrance system of this sort. This is on the assumption 
that there is a close correlation between school entrance monthly age and academic ability, so infrequent or rigid school entrance times can be harmful to the academic ability of students born at certain times of the year. Therefore, we need to try to be more flexible with the regulation of school entrance, finding a way to achieve this flexibility by widening the number of entrance time choices. In this way, we can narrow the academic ability gap which occurs among same grade students of different ages. 


\section{References}

Bell, J. F., \& Daniels, S. (1990). Are summer-born children disadvantaged? The birthdate effect in education. Oxford Review of Education, 16(1), 67-80.

Bibby, P. A., Lamb, S. J., Leyden, G., \& Wood, D. (1996). Season of birth and gender effects in children attending moderate learning difficulty schools. British Journal of Educational Psychology, 66, 159-186

Carroll, H. C. M. (1992). Season of birth and school attendance. British Journal of Educational Psychology, 62(3), 391-396.

Croll, P., \& Moses, D. (1985). One in Five: the assessment and incidence of special educational needs. London: Routledge.

Cosden. M., Zimmer, J., \& Tuss, P. (1993). The impact of age, sex, and ethnicity on kindergarten entry and retention decisions. Educational Evaluation and Policy Analysis, 15(2), 209-222.

Crosser, S. (1986). Summer birth date children: kindergarten entrance age and academic achievement. Journal of Educational Research, 79(6), 140-146.

Crosser, S. (1991). Summer birth date children: Kindergarten entrance age and academic achievement. Journal of Educational Research, 84(3), 140-146.

Davis, D. C., \& Trimble, C. S. (1978). Does Age of Entry into First Grade Affect Students' Achievement in School? Frankfort, Kentucky: Kentucky State Department of Education.

Dorset, Education Authority (1991). National Curriculum Assessment. Key Stage1, 1991: Final Evaluation Report. Dorchester: Dorset County Inspectorate.

Elkind, D. (1987). Miseducation. New York: Alfred A .Knopf.

Fogelman, K., \& Gorbach, P. (1978). Age of starting school and attainment at eleven. Educational Research, 21(1), 65-67.

Foxman, D., Ruddock, G., \& McCallum, I. (1990). APU Mathematics Monitoring 1984-88 (Phase2): A SumMary o $f$ the Finding, Conclusions and Implications. Assessment Matters, 3. London: EMU/SEAC.

Freyman, R. (1965). Further evidence on the effect of date of birth on subsequent school performance. Educational Research, 8(1), 58-64.

Gagne, F. (1985). Giftedness and talent: Reexaming a reexamination of the definitions. 
Gifted Child Quarterly, 29(3), 103-112.

Gardner, H. (1983). Frames of Mind: The theory of multiple intelligences. New York: Basic Books. Gilles, R. (1993). The effect of date of birth on performance within the secondary school. Science Review, 75(270), 133-135.

Gilmore, J. E. (1984). How summer children benefit from a delayed start in school. Paper presented at the 1984 annual conference of the Ohio School Psychologists Association. Cincinnati, $\mathrm{OH}$.

Gladwell, M. (2008). 아웃라이어(OUTLIERS): 성공의 기회를 발견한 사람들. 노정태(옮김, 2009). 서울: 김영사.

Hedger, K. (1992). Seen it; been there; done it: the analysis of GCSE examination results in Shropshire. Management in Education, 6(1), 29-33.

Jackson, B. (1964). Streaming: an educational system in miniature. London, Routledge \& Kegan Paul.

Jinks, P. C. (1964). An investigation into the effect of date of birth on subsequent school performance. Educational Research, 6(3), 200-205

Kinard, M., \& Reinherz, H. (1986). Birthdate effects on school performance and adjustment: a longitudinal study. Journal of Educational Research, 79(6), 366-372.

Massey, A., Elliott, G., \& Ross, E (1996). Season of birth, sex and success in GCSE English, mathenatics and science. Research Papers in Education, 11(2), 129-151.

Mayer, S. E., \& Knutson, D. (1999). Does the timing of school affect how much children learn? In S.E. Mayer, \& P.E. Peterson (Eds). Earning and Learning: How School Matters (pp. 70-102). Brookings Institution and Russell Sage Foundation.

Mortimore, P., Sammons, P,. Stoll, L., Lewis, D. \& Ecob, R. (1988). School Matters: the junior years. Wells.

Orme, J. E. (1962). Intelligence and season of birth. British Journal of Psychology, 35, 233-234.

Piirto, J. (2000). The Piirto Pyramid of Talent Development. Gifted Child Today, 23(6), 22-29.

Plomin. R. (1989). Environment and genes. American Psychologist, 44(2), 105-111.

Plomin, R. (1994). Nature, nurture, and social development. Social Development, 3(1), 37-53.

Russell, R. J. H., \& Startup, M. J. H. (1986). 'Month of birth and academic achievement'. Journal of Personal Individual Experience, 7(6), 839-846.

Sharp, C. (1988). Starting school at four. Research Papers in Education, 3(1), 64-90. 
Sharp, C. (1995). School Entry and the Impact of Season of Birth on Attainment. Slough: NFER.

Sharp, C., Hutchison, D., \& Whetton, C. (1994). How do season of birth and length of schooling affect children's attainment at key stage 1? Educational Research, 36(2), 107-121.

Shephard, L., \& Smith, M. (1986). Synthesis of research on school readiness and kindergarten retention. Educational Leadership, 44(3), 78-86.

Storfer, M. D. (1990). Intelligence and giftedness: The contributions of heredity and early environment. San Francisco: Jossey-Bass.

Sutton, P. (1967). Correlation between streaming and season of birth in secondary schools. British Journal of Educational Psychology, 37(1), 300-304.

Uphoff, J. (1990). School readiness and transition programs: Real facts from real schools. Rosemont. NJ: Modern Learning Press.

Wallingford, E. L., \& Prout, H. T. (2000). The relationship of season of birth and special education referral Psychology in Schools, 37(4), 379-387.

Wilson, G. (2000). The effects of season of birth, sex and cognitive abilities on the assessment of special educational needs. Educational Psychology, 20(2), 153-166.

Winner, E. (1997). Exceptionally high intelligence and schooling. American Psychologist, 52 (10), 1070-1081.

Ziegler, A. \& Heller, K.A. (2000). Conceptions of giftedness from a meta - theoretical perspective. In K.A. Heller, F.J. Mönks, R.J. Sternberg, \& R.F. Subtonik (Eds). International handbook of giftedness and talent (2nd ed.) (pp. 3-21). Oxford: Pergamon.

Крутецкий, В. А (1964). Вопросы психологии способностей школьников. Москва.

Лейтес, Н. С (1996). Психология одаренности и детей и подростков. Москва.

Хеллер, К А (1997). Диагностика и развитие одаренные детей и подростков: Осно вныле современные концепции творчества и одаренности. Москва: Молодая гвардил.

김태훈 (2011). 초등학교 취학나이가 대학진학에 미치는 영향. 노동경영논집, 34(1), 1-32.

이순주, 박찬웅 (2008). 출생월에 따른 학교입학연령과 과학영재교육원 영재선발. 영재교육연 구, 18(2), 239-264.

조석희, 이순주 (2001). 영재성의 개념과 판별. 영재교육담당교원 직무연수교재. 한국교육개발원. 통계청 (1998). 인구동태통계연보. 통계청.

홍후조, 김대석, 변자정 (2010). 학생의 생월과 학업성취의 관계. 교육학연구, 48(30), 99-124. 
* 논문접수 2011년 5월 2일 / 1차 심사 2011년 6월 3일 / 2차 심사 2011년 8월 24일 / 게재승인 2011년 9월 16일

* 이순주(李順珠 , Lee, SoonJoo): 한국교원대학교 초등교육과를 졸업하고, Moscow State University 심리학부에서 석사학위를 취득하였으며, 동 대학원 교육학부에서 박사학위를 취득하였다. 현재 국립한밭대학교 교양학부 교수로 재직 중이며, 주요저서로는 '서양 주요국가들과 영재교육' 등이 있다.

*e-mail : soonjoolee@hanbat.ac.kr

* 김경대(金敬大, Kim, KyoungDae): 한국교원대학교 물리교육과를 졸업하고, 동대학원 과학교육학과에서 석사 및 박사학위를 취득하였다. KAIST 과학영재교육연구원 교수를 거쳐, 현재 KAIST부설 한국과학영재학교 물리지구과학부에 재직 중이다. 주요저서로는 '대학과목선이수제의 운영과 활용' 등이 있다.

*e-mail : kkim@kaist.ac.kr 


\section{Abstract}

\section{아동의 출생월과 영재선발}

\section{이순주(李順珠)* 김경대(金敬大)**}

본 연구에서는 초·중·고 영재선발 과정에 응시한 아동, 영재로 선발된 아동의 계절별 출생률이 어떠한 양상을 나타내는지 그리고 계절별 출생률의 차는 어떠한지를 알아보았다. 그 결과, 일반 아동의 경우엔 겨울출생률이 높은 것으로 나타났으나 영재 선발 과정에 응시한 아동은 일반아와는 달리 봄출생아의 비율이 가장 높고 겨울 출생아의 비율이 가장 낮은 것으로 밝혀졌다. 또한 영재로 선발된 아동의 각 계절별 출생 비율에 있어서도 봄출생아가 가장 높고 겨울 출생아가 가장 낮은 것으로 나타나 영재 집단에서도 출생 계절에 따라 나이가 가장 많은 집단이 가장 높은 합격률을 보이는 것으로 나타났다. 즉 이들 영재 집단의 경우, 동 학년 아동 사이에 생겨나는 몇 개월의 나이차가 이들의 학업능력에 큰 의미를 지니는 것으로 해석되었다. 또한 영재선발에 있어 학교입 학월령이 미치는 영향을 조금 더 명확히 파악하기 위해 한 학년에서 나이가 가장 많은 집단인 $3 \cdot 4$ 월생과 나이가 가장 어린 $1 \cdot 2$ 월생 집단을 분석한 결과, 초·중·고등학교의 모든 영재합격자 집단의 $3 \cdot 4$ 월생 수가 $1 \cdot 2$ 월생보다 훨씬 더 많은 것으로 나타났으며 이러한 차이는 통계적으로도 매우 유의미한 것으로 나타나 $3 \cdot 4$ 월생이 초·중등 영재선발에서 매우 유리한 위치에 있음을 알 수 있었다. 본 연구를 통해 밝혀진 일련의 연구결과를 통해, 아동의 학교입학월령은 영재 선발에 중요한 요인으로 작용하며 초등학교 단계뿐만 아니라 고등학교 단계에까지도 아동의 학업능력형 성에 전반적으로 영향을 미친다는 것을 알 수 있었다. 이것은 영재선발 과정의 응시자뿐만 아니라 1 차, 2차, 3차 영재선발 그리고 최종 합격자에서도 봄출생아의 비율이 높은 현상이 4-5년여에 걸쳐 실시된 초·중·고 영재선발과정에서 비교적 일관되게 나타나는 연구 결과에 의해 뒷받침되고 있다. 이렇듯 한 아동이 어린 시기에 학교를 입학하느냐 또는 좀 더 늦은 시기에 학교를 입학하느냐 의 문제가 일반 아동의 학업능력뿐만 아니라 초·중·고 영재선발에까지도 영향을 미치는 주요 요인으로 작용한다는 분석결과를 통해, 우리는 타 아동보다 상대적으로 어린 나이에 학교를 입학 해 열세한 학업능력을 가질 가능성이 있는 아동을 위한 제도 개선 방안이나 교수방법을 적극적으 로 모색할 필요가 있을 것으로 사료된다.

주요어: 학교입학월령, 영재선발, 영재아, 나이차, 응시자, 합격자, 출생계절 